Massimo Leone*

\title{
City of Nostalgia: The Semiotics of Urban Retrotopias
}

\begin{abstract}
The Casa da Nostalgia, or "Nostalgic house," in the Taipa area of the special administrative region of Macau, is a museum devoted to temporary exhibitions reconstructing everyday life in the city, especially in the epoch of Portuguese ruling. Just opposite the museum, on the other side of a large pond, a giant casino, the Venetian Macau, reproduces Venice both with its external architecture and its interior design. The article analyzes these two urban settings in order to develop a semiotic understanding of as many ways of symbolically reconstructing cities. On the one hand, cities can be reconstructed in a nostalgic form; the essay inquires on the origin and the consequences of urban nostalgia; on the other hand, cities can be reconstructed as ersatz. The article further investigates the dialectics between predominantly temporal or prevailingly spatial urban reconstructions, with reference to the socio-cultural dynamics that have changed Macau in the last decades. The article concludes with the methodological suggestion that the study of urban re-constructions requires the combined efforts of several disciplines, jointly investigating why, how, but also to what effect cities are re-built.
\end{abstract}

Keywords: city reconstruction; ersatz cities; Macau; nostalgic cities; Venice; urban semiotics

*Corresponding author: Massimo Leone, Shanghai University, Shanghai, China /University of Turin, Turin, Italy, e-mail: massimo.leone@unito.it

La vida es un pequeño espacio de luz entre dos nostalgias: la de lo que aún no has vivido y la de lo que ya no vas a poder vivir. Y el momento justo de la acción es tan confuso, tan resbaladizo y tan efímero que lo desperdicias mirando con aturdimiento alrededor. 


\section{Nostalgia at home}

Walking along Avenida da Praia, in Macau, past the church of the Nossa Senhora do Carmo and the adjacent garden, one comes across an array of five villas known as Casas da Taipa, "Taipa” being one of the islands of the special administrative region of Macau. Built in 1921 as residences for high-rank public officers, these villas strike the visitor for the subtly elegant curves of their art deco facades, in delightful pale green color. In 1999, the Government of Macau transformed the architectural complex into the Casas-Museu da Taipa (Museum Houses of Taipa), ${ }^{1}$ which in 2006 were turned into as many exhibition centers: Museu Vivo Macaense (Macau Living Museum), Galeria de Exposições (Gallery of Exhibitions), Casa Criativa (Creative House), Casa de Recepções (Reception House), and Casa de Nostalgia, curiously translated not simply as House of Nostalgia but as Nostalgic House (Figures 1-3).
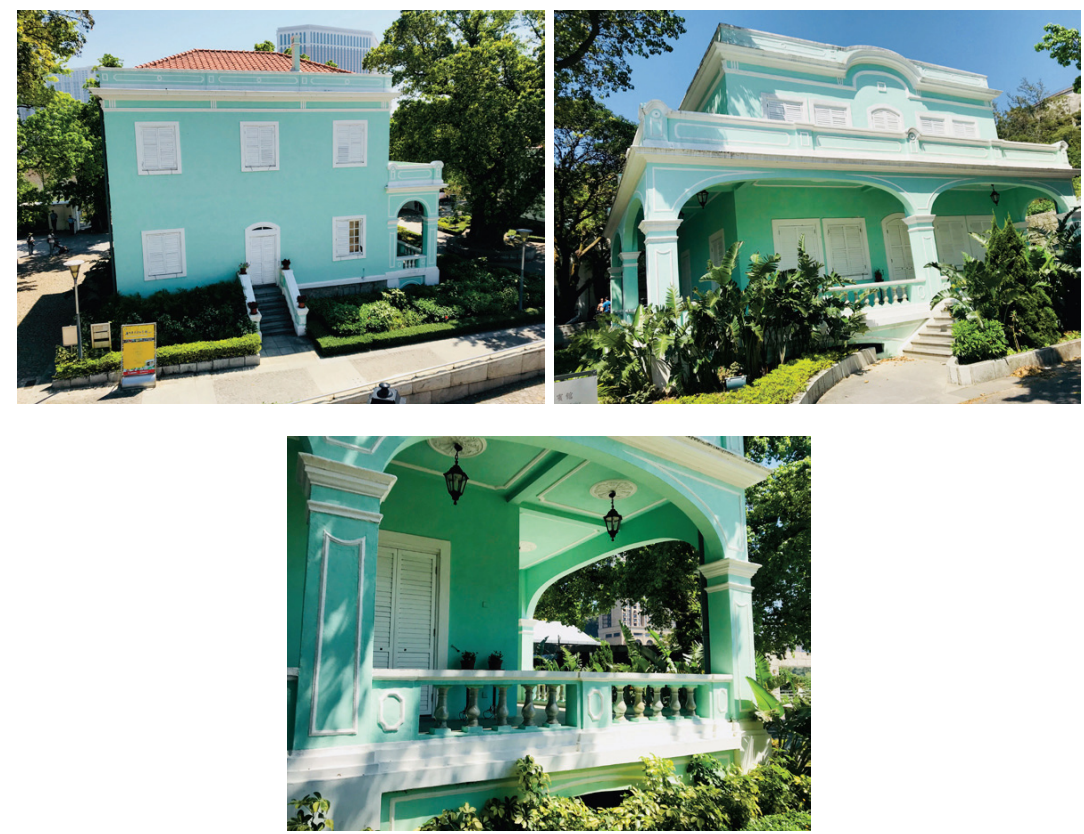

Figures 1-3: The Casas-Museu da Taipa (Museum Houses of Taipa), Taipa, Macau; photographs by the author (2018)

1 Unless differently specified, all translations in the article are by its author. 
The purpose of this last villa, already explicit in its name, is further explained at the entrance (Figures 4-5):

A Casa de Nostalgia visa, mediante a realização não periódica de exposições temáticas relacionadas com Macaenses e o desenvolvimento do Cotai, mostrar a respectiva vida popular, religião, arquitectura e gastronomia, entre outras componentes, por forma a reflectir o passado e a actualidade dos Macaenses e do Cotai.

[The Nostalgic House aims, through the non-periodic realization of thematic exhibitions related with the Macaenses and the development of Cotai, at showing their everyday life, religion, architecture, and gastronomy, among other components, as a way to reflect on the past and the actuality of Macaenses and Cotai].
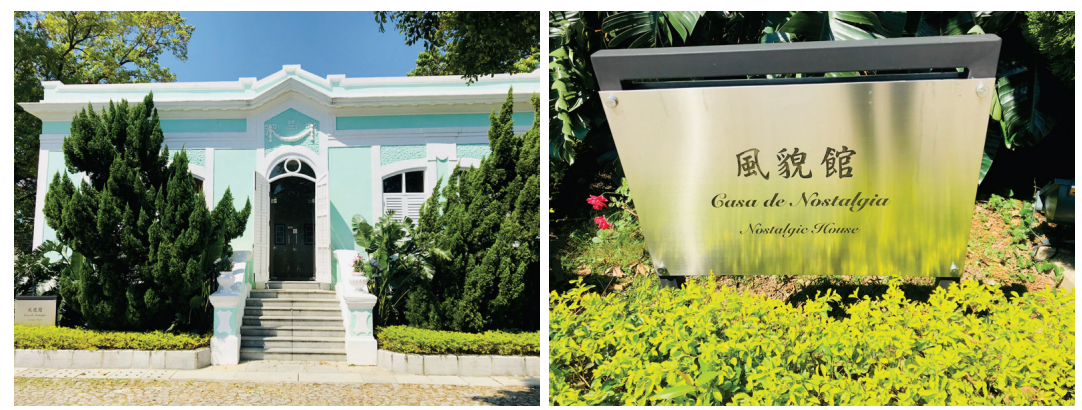

Figures 4-5: Casa da nostalgia (Nostalgic House); photographs by the author (2018)

"Nostalgia" is clearly the main undertone of the other villas too, and especially of the Museu Vivo Macaense, which recreates scenes of everyday life from the past of Macau (Figures 6-10). On the one hand, both villas, the Nostalgic House and the Living Museum of Macau, are described as focusing also on the "actuality" of Macaenses, on their present-day life; on the other hand, it is evident that this representation of current Macau is not emotionally neutral but explicitly constructed in a sentimental framework of nostalgia. 

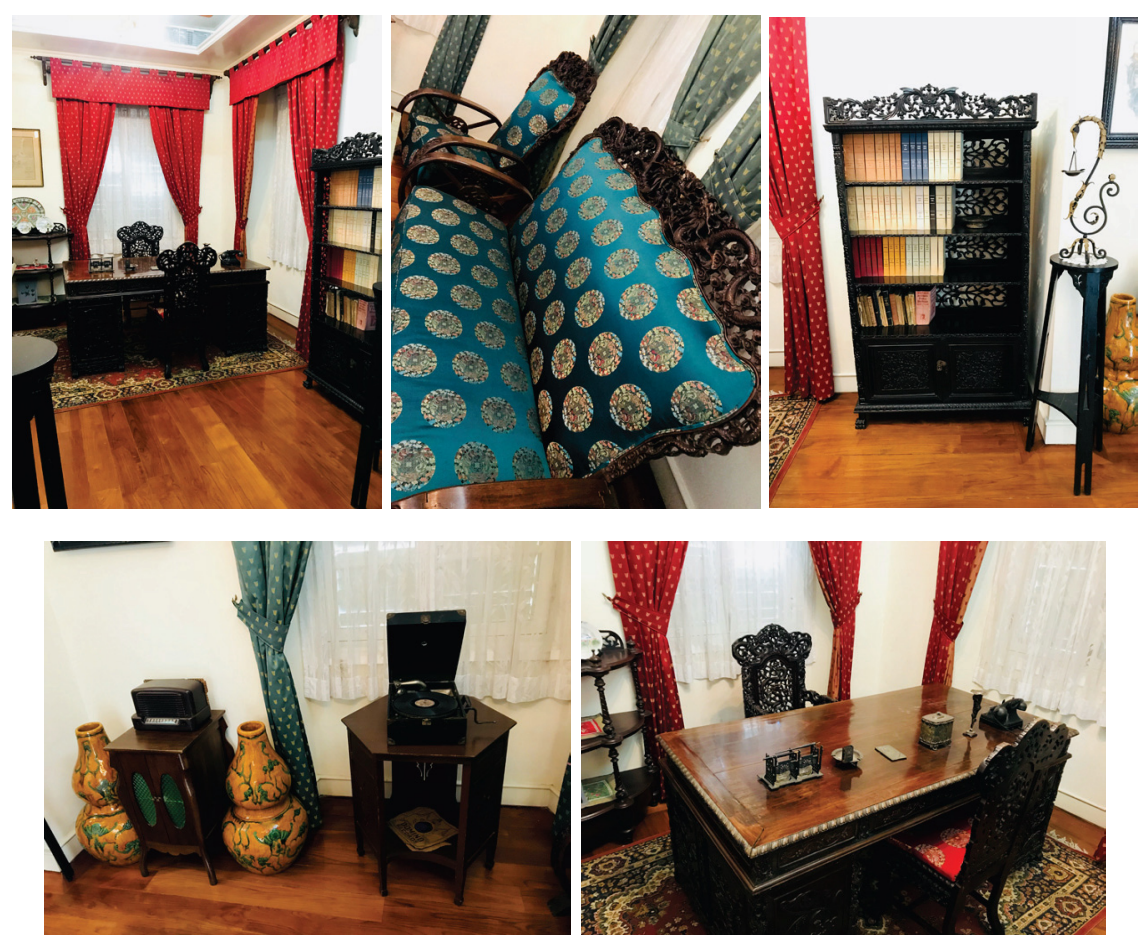

Figures 6-10: Museu Vivo Macaense (Macau Living Museum); photographs by the author (2018)

\section{The invention of nostalgia}

The etymology of the word "nostalgia" is of primary interest in relation to the theme of urban reconstruction. French physician Johannes Hofer $^{2}$ invented the term in his doctoral dissertation for the Faculty of Medicine at the University of Basel, Switzerland, in $1688 .^{3}$ In the second paragraph of his Dissertatio medica de nostalgia, Hofer explains that "nostalgia" is the medical neologism through which he intends to designate and study that which the Swiss call das Heim-

2 Mulhouse, France, 27 April 1669- 26 March 1752.

3 On the dissertation and its cultural context, see Pfannkuche 1978. 
$w e h^{4}$ and which, he continues, the French call la Maladie du Pays (both translatable in English as "homesickness") (Figure 11).

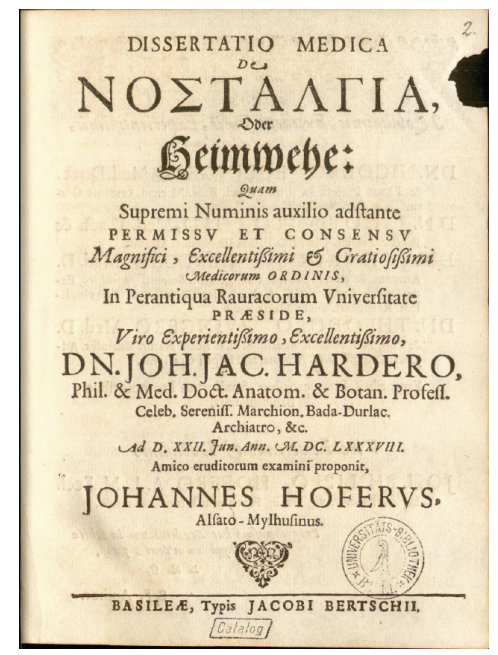

Figure 11: Johannis Hofer’s Dissertatio medica de nostalgia (1678)

"Nostalgia," Hofer specifies, is composed of the Greek words nosos, that is, 'return to the homeland,' and algos, that is, 'pain' or 'sadness.' Hofer's first definition on nostalgia is, therefore, the following: ut adeo ex vi vocis nosalgia designare possit tristem animum ex reditus in patriam ardenti desiderio oriundum (so that by this word, "nostalgia", we might designate the sadness of the soul stemming from an ardent desire for going back to one's homeland). Hofer makes a linguistic mistake that is, nevertheless, revealing. He confounds the term nosos, which actually means 'disease,' and nostos, which designates the returning home, often with heroic or even mythical connotations. As Julius Pokorny points it out in his Indogermanisches etymologisches Wörterbuch (1959 2: 766), the word nostos comes from the Indo-European root nes-, referring to the semantic area, in German, sich vereinigen, geborgen sein, 'to get reunited', and the root hasta, that is, in German, Heimat, 'home.'

Hofer writes nosalgia, which would actually mean 'the pain of disease,' but intends, instead, nostalgia, that is, 'the pain of a hindered return home.' He even proposes, but soon discards, two alternative designations: nosomania (that is, nostomania), a failed neologism that would have meant 'the obsession for

4 Cfr Fritz 1949. 
returning home' and philopatridomania, another failed neologism meaning 'the maniacal attachment to one's homeland'; we shall see that these terms might actually turn useful later on in the article, so as to describe certain aspects of the semiotics of nostalgic urban reconstruction.

A second important step in the history of the word "nostalgia" is the publication, in 1796, of Zoonomia, or, the laws of organic life, by Erasmus Darwin, ${ }^{5}$ grandfather of Charles. Erasmus Darwin lists nostalgia among several types of "madness." After dealing with mania mutabilis, studium inane, vigilia, erotomania, and amor sui, Darwin grandfather defines nostalgia as the "unconquerable desire of returning to one's native country, frequent in long voyages, in which the patients become so insane as to throw themselves into the sea, mistaking it for green fields or meadows" (1796: 37). He adds, significantly, that "the Swiss are said to be particularly liable to this disease, and when taken into foreign service frequently to desert from this cause, and especially after hearing or singing a particular tune, which was used in their village dances, in their native country, on which account the playing or singing of this tune was forbid by the punishment of death” (1796: 37) (Figure 12).

\section{ZOONOMIA ;}

\section{OR THE $\cdot$ \\ LAWS OF ORGANIC LIFE.}

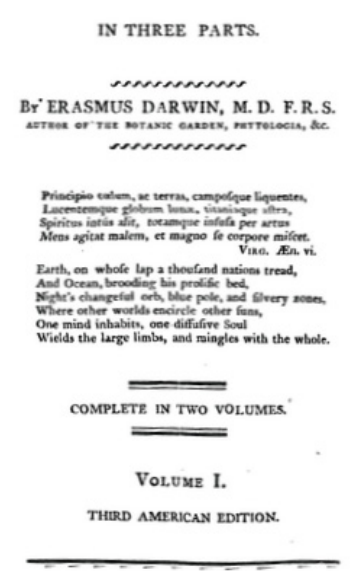

Figure 12: Erasmus Darwin's Zoonomia (1796)

5 Elston, UK, 12 December 1731 - Breadsall, UK, 18 April 1802; on his life and works, see Krause and Darwin (Charles) 1880. 


\section{Types of urban nostalgia}

Opposite the Casa da nostalgia in Taipa, Macau, one comes across Venice (Figure 13).

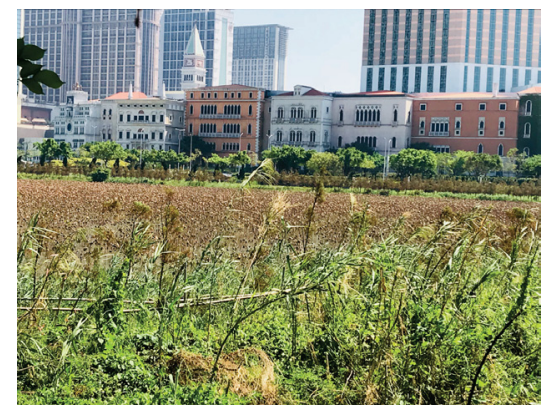

Figure 13: The Venetian Macao; photograph by the author (2018)

The gaze widens over a vast stretch of swamp, a no man's land of mud and lotus flowers, beyond which an array of pastel buildings, transpierced by Moresque windows, emerges in a dazzle of heat and damp; all of a sudden, nostalgia for a distant space and its remote time is replaced by amusement facing that which should be unique, and about to be lost forever in the emerging waters of the lagoon, and which nevertheless reappears over and over again like the phoenix of the Venetian theater, for instance in California, in little but expensive scale, or in London, in a discreet maze of channels peppered by colorful boats, and above all in Las Vegas, a majestic resurrection of Venice with its campanile towering over the near desert but towered by the adjacent casinos, and then again here, transported from Italy to this corner of China, as if the barges of the empire had been able to magically take from the other side of the silk road not only textiles, and paintings, and mirrors, but the entire city, eradicated with its whole body, with the house of Marco Polo, and the palace of the doge, and the ever-recurring campanile, until this city of mad spirits fluctuating over water rematerialized here, right in front of the house of nostalgia, in Macau (Figures 14-18). ${ }^{6}$

6 The Venetian Macao (Chinese: 澳門威尼斯人) is a luxury hotel and casino resort in Macau owned by the American Las Vegas Sands company. It is a 39-story casino hotel on the Cotai Strip. The 10,500,000-square-foot $\left(980,000 \mathrm{~m}^{2}\right)$ casino resort is modeled on The Venetian Las Vegas. The Venetian Macao is the largest casino in the world, the largest single-structure hotel building in Asia, and the seventh-largest building in the world by floor area. The main hotel tower was finished in July 2007 and the resort officially opened on 28 August 2007. It has 3,000 

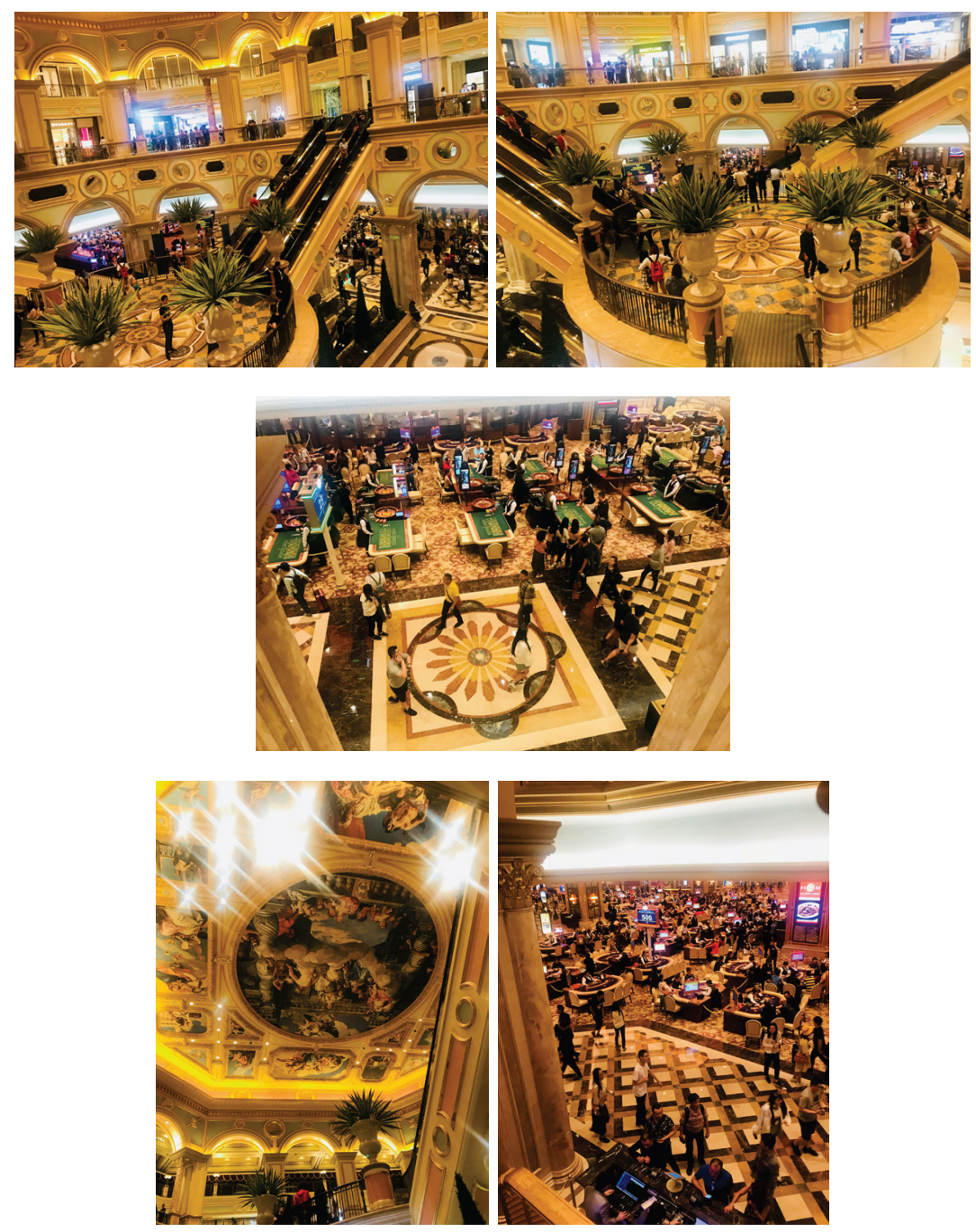

Figures 14-18: The Venetian Macau; photographs by the author (2018)

suites, $1,200,000 \mathrm{sq} \mathrm{ft}\left(110,000 \mathrm{~m}^{2}\right)$ of convention space, 1,600,000 sq ft $\left(150,000 \mathrm{~m}^{2}\right)$ of retail, 550,000 square feet $\left(51,000 \mathrm{~m}^{2}\right)$ of casino space - with 3,400 slot machines and 800 gambling tables and the 15,000-seat Cotai Arena for entertainment and sports events. The lead architect for the Venetian Macao were Aedas and HKS, Inc. joint venture. 


\subsection{The indexicality of nostalgia}

There are, indeed, different ways of re-presenting and re-constructing a city. They can be ranged across a spectrum that measures the relation between the ideal type and the real token that the reconstruction manifests. On the one hand, there is the impossible dream of a replica: inhabiting the past as it once was in time but also in space, with all its nuances, and the abysses of lost memories. That is a utopia of reconstruction that reminds one of the impossible dream of Gatsby, of the excruciating illusion of reversing the arrow of time so as to grasp a lost integrity, the street of one's childhood or - an even more tragic impossibility - the innocence of a city before the war (Leone 2009). It is a sad, sometimes pathetic utopia, which expresses itself in architecture as well as in the other arts. Its architectural failure is often macroscopic, similar to that of the aging beauty that seeks to retrieve the perfection of a lost face: the reconstructed city will look like the destroyed one prior to its annihilation, like the old Nikolaiviertel (Figure 19), yet an unmistakable flair of ersatz will emanate from the renewed walls, like the perfect yellow walls of Berlin's reconstructed pristineness.

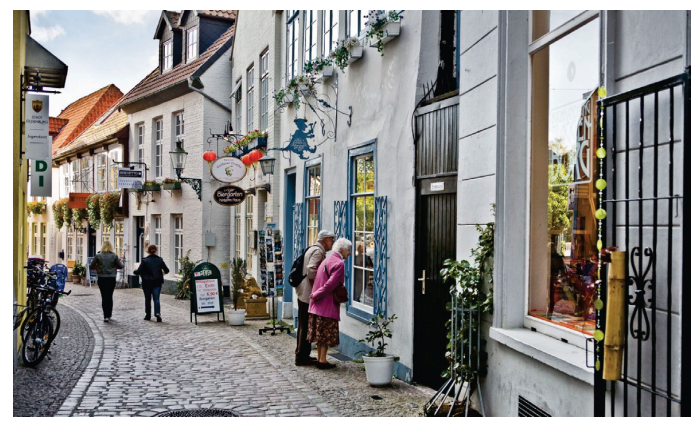

Figure 19: Nikolaiviertel, Berlin; photograph by the author (2018)

In the terms of Peirce, the less indexical a replica is, and the less iconic it is, and as a consequence the more symbolical it is, the less it will suffer from the inexorable decay of time, from the impossibility of reversing its arrow (Leone 2018). Entire literary poetics have been devoted to restoring cities that are no more. Reading Patrick Modiano, ${ }^{7}$ for instance, one comes across streets, and places, and vendors, and minute everyday details of neighborhood existence,

7 Boulogne-Billancourt, Paris, 30 July 1945. 
which are inevitably lost in the three-dimensional life of post-war Paris and that no project of architectural reconstruction will ever be able to revive.

\subsection{Faking time out of space: Ersatz cities}

On the other hand, the utopia of replication might yield to the necessity of sacrificing either the re-production of time, or the re-production of space. As regards the former possibility, Venice in the casino area of Macau looks very similar, or at a certain distance even identical, to the prototypical Venice, for it recuperates the same idea of freezing a city in time that all historical touristy urban places treasure: as Venice cannot change, but must remain faithful to what it was at the time of its prototypical peak, so any reproduction of Venice must mechanically refer to that ideal time, without introducing any element that might lead memory and imagination to a different and presumably more recent eon. How ironically bitter, then, is the feeling of the visitor who, having penetrated into the casino, and having been surrounded by the gilded perfection of the reproduction, with all its glaring stuccos and laced windows and marble balconies and curvy bridges and triumphant Tiepolos, suddenly comes across a blue canal, indeed too blue to be truly Venetian, and, afloat in the middle of this blue, like a black insect on a cobalt stream, the perfect reproduction of a gondola, stirred by a gondolier who is himself prototypically Italian, with slender legs, and muscled torso, and perfectly shaved neck...but then, as the gondola approaches, the visitor is doomed to realize that it is not propelled by the prodigious vertical rowing of the handsome gondolier but by a little and annoyingly buzzing engine, which drags the elegant boat along a underwater rail (Figures 20-23).

This sudden surprise of infidelity and artificiality comes about because the utopia of reconstruction through a replica that freezes time only is, nevertheless, unfaithful to space: mimicries of early modern Venice do not appear in the middle of a lagoon but in that of a desert and riddle of giant casinos, like in Vegas, or at the outskirts of a quiet urban neighborhood, like in London, or at the periphery of an Asian peninsula, like in Macao. The fake Venice iconically reconstructs the real one, with its temporal fixity, and this iconic reproduction rekindles, in turn, the symbolical aura of the city, yet the space of the replica is totally different, and the context as a consequence preposterous, and that aura which the name itself of Venice can conjure up in the visitor's mind persists only if the visitor has no actual idea of what the real Venice might look like, with its enchanting enigma of spatial and temporal indexicalities. The Venice of 
Macau is like the relic of an early modern saint transplanted in the body of a cyborg.
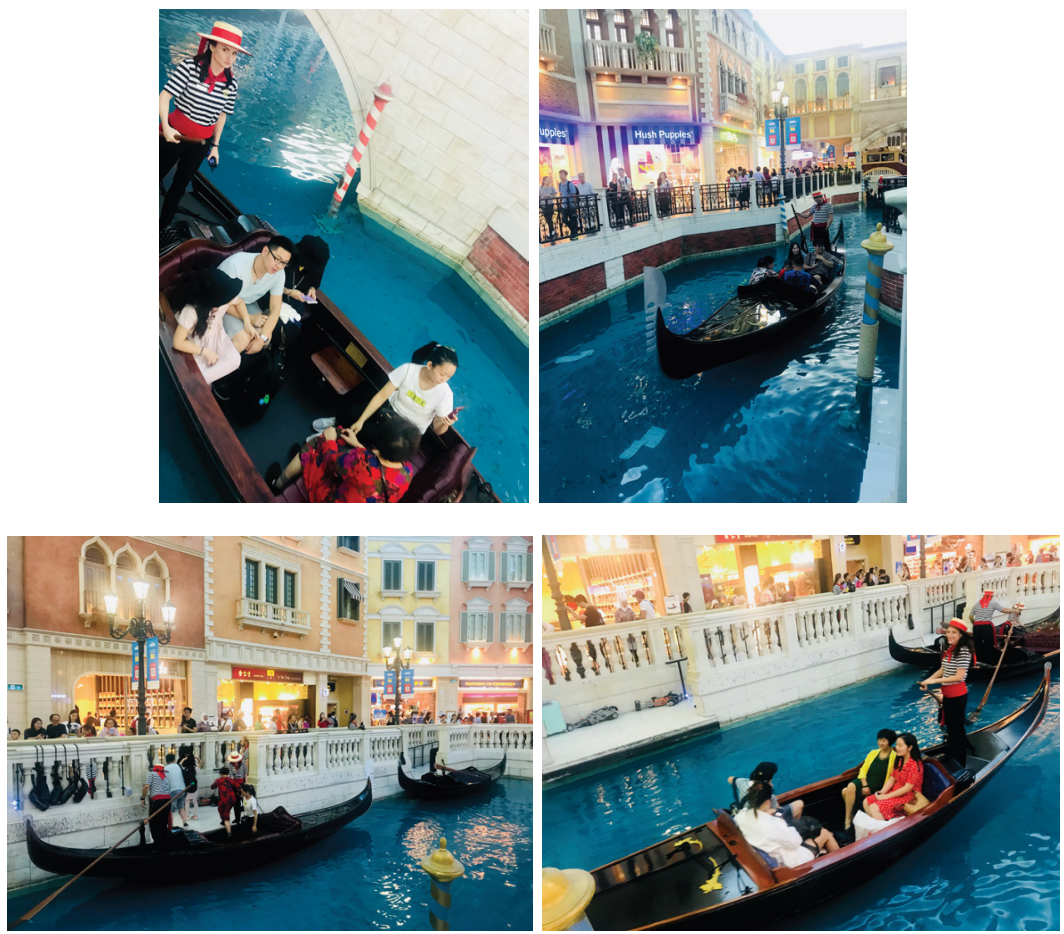

Figures 20-23: Gondolas and gondoliers in The Venetian Macau; photographs by the author (2018)

\subsection{Faking space out of time: Ghost cities}

But reconstruction can also proceed toward a different direction along the spectrum of indexicality, and be faithful to space more than to time. If attention to the utopia of temporal crystallization gives rise to ersatz cities, obsession with the utopia of space and the immutability of the aura that surrounds a certain locus brings about urban ghosts. Such is the city evoked in nostalgic reconstructions, in which the actual urban settlement is not anymore, suppressed in an urbicidio - as Francesco Mazzucchelli designates the intentional annihilation of a city (2010) - but emerges like a phantom from the fogs of memory in the form of a myriad of references to what once was and is now no longer, to the minute intrigue of images that are detailed enough to 
elicit the mental reconstruction of a lost city but not concrete enough to experience the sensorial phenomenology of its actual resurrection. In the Casa de Nostalgia of Macau, for instance, pictures of anonymous parties hang from the walls, displaying a plethora of faces about which what is lost is not only the faces themselves, and the identity of names and ages and lives that they would carry with them, but the types themselves of faces, faces that would once appear everywhere in the city, and constitute its living lymph, and that now are not only non-existent but also melancholically obsolete, like specimens of species extinct forever. Their pictures become an object to be preserved by a museum (Figure 24).

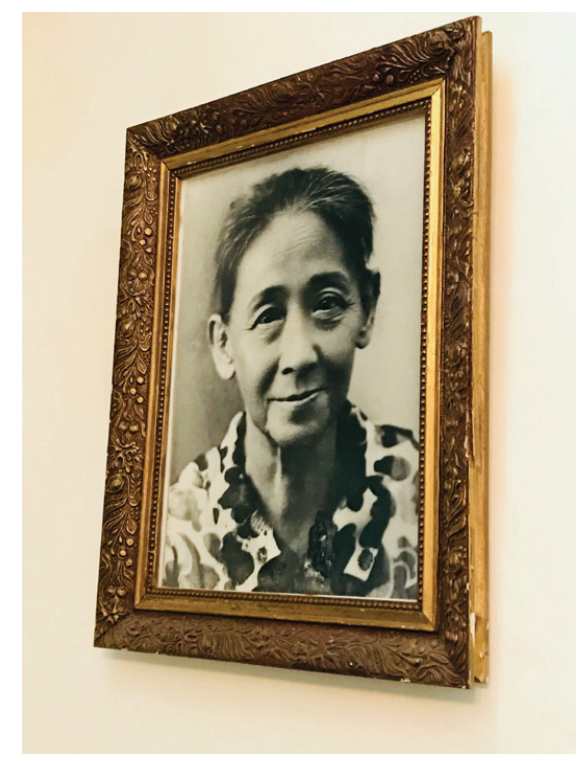

Figure 24: A lost face of Macau in the Casa de Nostalgia, Macau; photograph by the author (2018)

That happens in every society: faces evolve, their shape evolves, as well as the color of their skin, and when old faces are gone, the city where they would once appear goes by as well: old pictures of Italian cities are nostalgic not only because the palaces, the streets, the squares, etc. would look different, but also the faces, the color of their skin, the shape of the eyes, the expression of ancient emotions appearing therein. 


\section{The dialectics of ersatz and phantom}

The nostalgic reconstruction of a city, therefore, draws the silhouette of a ghost that appears in the right space, but at a displaced time. In Macau's Venice, one has the impression of being able to be in the real Venice at the very time of its glory, albeit in a different space, whereas in nostalgic Macau, one has the impression of being able to be in the real Macau in the space of its glory, albeit at a different time. The imperfection of the former reproduction brings about a feeling of pathetic artificiality, whereas the imperfection of the latter reproduction brings about a feeling of pathemic nostalgia. In the first case, one finds in the wrong space the right time, whereas in the second case, one finds the wrong time in the right space. The two forms of incompleteness, however, stay in a dialectic relation, the nature of which is multiple. At the purely aesthetic level, the nostalgia that the Casa de Nostalgia is able to trigger in its visitors also depends on the fact that the version of Macau that it nostalgically depicts has not only disappeared, but has also been superseded by a different Macau, which is exactly the one rising with its gigantic and extravagant casino palaces at the other side of the lagoon.

The dialectic, however, also acquires socio-historical undertones: if the Casa de Nostalgia exists, and if nostalgia has become the predominant feeling of Macau to such an extent that a museum is dedicated to it and to the melancholic rekindling of a time that is no more, it is exactly because the city has evolved in a different direction. Perhaps the concept of urbicidio should be, in this as in similar cases, expanded and refined: a city disappears not only because it is physically destroyed, but also because it is progressively parasitized by a second, different city that grows inside the first one, first like an alien presence, then replacing its inner core. Macau's current sociolinguistics is a perfect example of this process: the streets of the former Portuguese colony are covered with writings in the language of Camoẽs, and even in buses and metros one hears robotic voices spelling the names of the stations in Portuguese, yet it is evident that a sheer minority of the population now speaks this language, whose status is exactly that of an empty shell inside which an essentially Chinese speaking-city has grown and continues to grow (Radwańska-Williams 2018).

The socio-commercial destiny of Macau is, then, particularly paradoxical. ${ }^{8}$ The city had acquired, because of its political and social history, the status of an

8 For an introduction to the history of Macau, see Hau 2011, Xue 2013, and Basto da Silva 2015. 
urban heterotopia. It existed, like Hong Kong, according to a different ideology, also and above all because of its mixed Portuguese and Chinese identity, once merged in the Macaense one, and expressing itself in the bilingual and bicultural nature of Macau's society (Silva 2015). With the progressive withdrawal of the Portuguese component, however, Macau's heterotopia too has become an empty shell, which has been adopted, then, so as to locate a different heterotopia, not any more that of a contact between China and Portugal, Asia and Europe, East and West, but the internal ideological heterotopia of the present-day mainland Chinese society, opposing tradition and innovation, industrious parsimony and squandering frenzy, rootedness on the one hand and, on the other hand, an increasing passion for traveling, exoticism, and a growing phenomenon of "Occidentalism", involving, among other things, the utopian perception of Venice as globally prestigious touristy destination. ${ }^{9}$ That is why the slow destruction of Macau through progressive emptying and re-filling has given rise, on the one hand, to the opportunity of reconstructing its identity as exotic gate to cultural otherness through the lucrative business of casinos (Al 2018); Casinos, in Macau, daily welcome thousands of mainland citizens so as to grant them an ersatz of traveling to Europe as well as a radical alternative to the traditional Chinese way of living, working, and even enjoying vacations. On the other hand, the same destitution of old Portuguese Macau gives rise to a ghost re-construction, the one of the Casa de Nostalgia, which ultimately targets a different audience, that of visitors of mostly Western, European, and even Macaense descent, so as to provide them with a temporal exotic experience, opposite but complementary to the spatial exotic experience provided by the nearby casinos.

\section{Conclusions: Reconstructing semiotics}

The case of Macau suggests that the study of urban re-constructions requires the combined efforts of several disciplines, jointly investigating why, how, but also to what effect cities are re-built. The first question, "why", is a matter for historical and sociological inquiry: these disciplines should find out what socioeconomic trends and political changes have brought about the progressive destitution of Macau as a Macaense city and its parallel re-building as Chinese heterotopia. The second question, "how", should be addressed by urban

9 On the development of the "new" Macau, see Wei 2014. 
planning and architecture: erasing the memory of the old Macau in favor of the new one results, on the one hand, from macro-alteration of the urban fabric, such as the construction of several gigantic casinos - mostly with fanciful shapes and exotic connotations - at the heart of the city; on the other hand, it results from micro-changes in the totality of the city as its population's demographic, ethnic, and linguistic composition change, also under the pressure of casino development. The Macaense architecture of Macao owed its distinctive flavor to the delicate balance between Portuguese and Chinese stylistic elements, for instance in its delightful squares, some of which, like Praça Lilau (Figure 25), are still surviving for the sake of tourists; in these squares, the typical tiled pavement of Portuguese urban centers coexists with pagoda-kiosks and decorative Chinese calligraphy (Dias 2005). As elements of distinctive Chinese descent replace those of Portuguese origin, however, the old binomial architecture yields to a characteristically mainland China atmosphere, pervading first the suburban areas of the city, then progressively conquering its inner core (Fernandes, Janeiro, and Janeiro 2015).

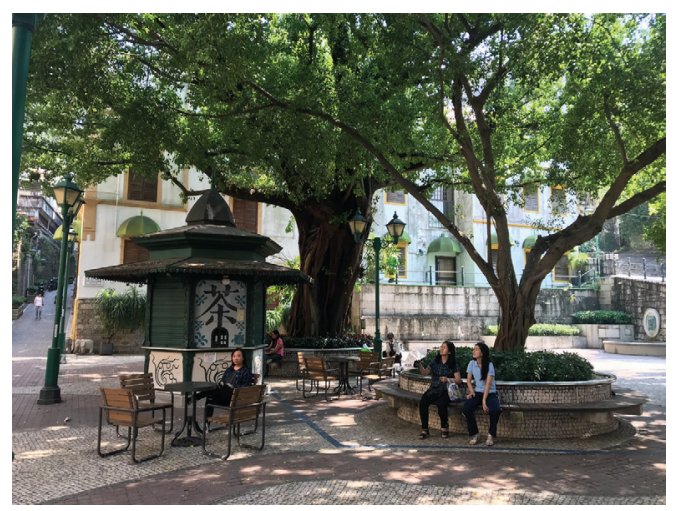

Figure 25: Praça Lilau, Macau; photograph by the author (2018)

In the study of urban re-construction, however, there is place and need for semiotics too, ${ }^{10}$ a discipline that should cooperate with the first two orders of study but also develop a specialization in the explanation of the effects of meaning produced by the urban re-construction. In the case of Macau, for instance, the two neologisms discarded by Hofer come in handy: the continuous emphasis on the heterotopic aspect of Macau, either as a ghost of a Portuguese

10 See, for instance, Zhen Sun and Wei Luo 2018. 
heritage that is now being progressively lost or as non-lieu where mainland Chinese gamblers can dream of a different space with alternative rules, turns Macau into a city where one must either live time without space, as in the casino re-construction of a frozen early modern Venice, or space without time, as in the Casa de Nostalgia. The latter vacuity gives rise to a nostomania, to a thirst for returning to a pristine past that is now impossible to quench, whereas the former brings about a philopatridomania, an exceeding passion for a homeland that does not exist any longer but is reconstructed in an empty ersatz.

There is no better image to symbolize this social, architectural, and semiotic condition than that of Macau's most famous landmark, the Jesuit church of Saint Paul (Guillen-Nuñez 2009). The church now stands only as an empty façade, attracts with its hollow splendor thousands of tourists a day, has them approach its majestic architecture, take myriads of selfies in front of it, and trespass its gates, but only to let them discover, with bitter hindsight, that beyond the façade there is nothing, that the simulacrum is just an illusion, and that the past shows itself in Macau with a façade, but not with a face (Figure 26).

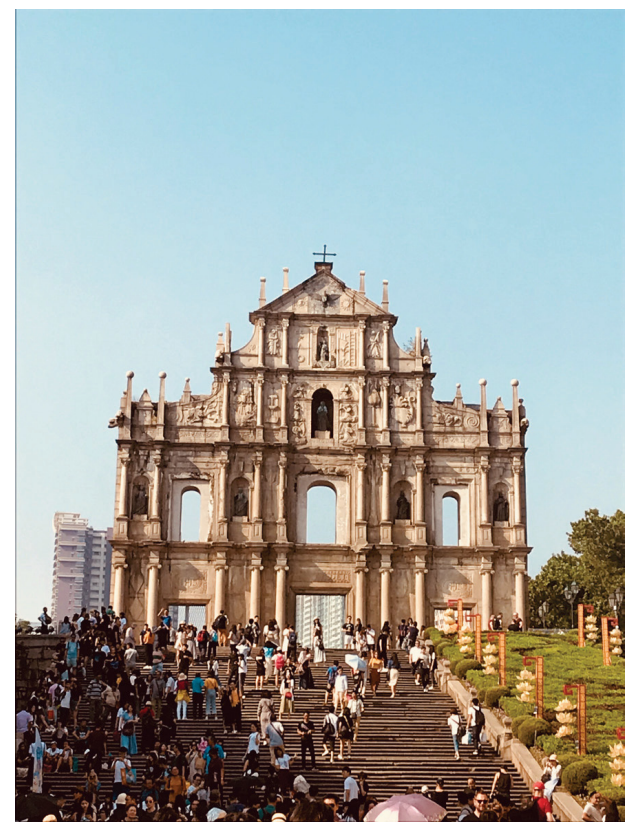

Figure 26: Ruins of the church of Saint Paul; photograph by the author (2018) 
Acknowledgment: A first version of the present essay was delivered as a keynote speech at the symposium "R3 Workshop: Re-Constructing Cities, ReAssembling Memories, Re-Defining Identities”, Syracuse, University of Catania, 16-17 November 2018, organized by Francesco Mazzucchelli and Maria Rosaria Vitale.

\section{References}

Al, Stefan (ed.). 2018. Macau and the casino complex. Reno, NA: University of Nevada Press.

Aresta, António and Celina Veiga de Oliveira. 2009. Macau: Uma história cultural. Mem Martins: Inquérito; Lisbon: Fundação Jorge Álvares.

Basto da Silva, Beatriz. 2015. Cronologia da história de Macau. Macau: Livros do Oriente.

Krause, Ernst and Charles Darwin. 1880. Erasmus Darwin und seine Stellung in der Geschichte der Descendenz-Theorie; mit seinem Lebens- und Charakterbilde von Charles Darwin. Leipzig: Ernst Günther's Verlag.

Dias, Pedro. 2005. A urbanização e a arquitectura dos portugueses em Macau, 1577-1911. Lisboa: Portugal Telecom.

Fernandes, José Manuel, Maria de Lurdes Janeiro, and Maria João Janeiro (eds.). 2015. Macau: Cidade, território e arquitecturas. Macau: Instituto Internacional de Macau.

Fritz, Ernst. 1949. Vom Heimweh. Zürich: Fretz \& Wasmuth.

Guillen-Nuñez, Cesar. 2009. Macao's Church of Saint Paul: A glimmer of the Baroque in China. Hong Kong: Hong Kong University Press; London: Eurospan.

Hao, Zhidong. 2011. Macau history and society. Hong Kong: Hong Kong University Press. Hofer, Johannis. 1678. Dissertatio medica de nostalgia. Basel: Typis Jacobi Bertschii. Leone, Massimo. 2009. Policlastia - Una tipologia semiotica. In Massimo Leone (ed.), La città come testo: scritture e riscritture urbane/The city as text: Urban writing and re-writing (theme issue), Lexia 1-2. 335-356.

Leone, Massimo. 2018. The roots of textual energy: The semiotics of motivation and demotivation. In Massimo Leone, Luca Rizzo, and Pier Carlo Tommasi (eds.), Texts in between action and non-action: Genesis, strategies, and outcomes of textual agency, 451460. Special issue of Annali di Ca' Foscari, serie orientale 54(1); e-ISSN 2385-3042; ISSN 1125-3789; DOI 10.30687/AnnOr/2385-3042/2018/01/021.

Mazzucchelli, Francesco. 2010. Urbicidio: Il senso dei luoghi tra distruzioni e ricostruzioni nella ex Jugoslavia. Bologna: Bononia University Press.

Pfannkuche, Klaus Jürgen. 1978. Johannes Hofers Dissertation “De Nostalgia' (1678) und die zeitgenössische Medizin.” Thesis (doctoral), Philipps-Universität, Marburg.

Pokorny, Julius. 1959 [i.e. 1948-1969]. Indogermanisches etymologisches Wörterbuch, 2 vols. Bern: Francke.

Radwańska-Williams, Joanna. 2018. Reading the city: The linguistic and semiotic landscape of Macao's San Ma Lo. In Andy Curtis and Roland Sussex (eds.), Intercultural communication in Asia: Education, language and values, 139-180. Cham, CH: Springer. 
Silva, António M. Jorge da. 2015. Macaenses: The Portuguese in China. Macau: Instituto Internacional de Macau.

Wei, C. X. George. 2014. Macao: The formation of a global city. Milton Park, Abingdon, Oxon; New York, NY: Routledge.

Xue, Fengxuan. 2013. Macau through 500 Years: Emergence and development of an untypical Chinese city. Singapore: Silkroad Press.

Zhen Sun and Wei Luo. 2016. Gendered construction of Macau Casino: A social semiotic analysis of tourism brochures. Leisure Studies 35(5). 509-533.

DOI: $10.1080 / 02614367.2015 .1009847$

\section{Bionote}

\section{Massimo Leone}

Massimo Leone (b. 1975) is full professor of Semiotics at the University of Turin and, part time, at Shanghai University. His research interests include cultural semiotics, urban semiotics, visual semiotics, and the semiotics of religion. His publications include Religious conversion and identity: The semiotic analysis of texts (2004), Saints and signs: A semiotic reading of conversion in early modern Catholicism (2010), Sémiotique du fundamentalisme: messages, rhétorique, force persuasive (2014), and A cultural semiotics of religion (in Chinese, 2018). 